\title{
FORMULASI NANOPARTIKEL EKSTRAK BAWANG DAYAK (Eleutherine americana (Aubl) Merr) DENGAN VARIASI KONSENTRASI KITOSAN- TRIPOLIFOSFAT (TPP)
}

\author{
Ermina Pakki, Sumarheni, Aisyah F, Ismail, Syarfina Safirahidzni \\ Fakultas Farmasi, Universitas Hasanuddin, Makassar, Indonesia
}

\begin{abstract}
ABSTRAK
Ekstrak etanol Bawang dayak (Eleutherine americana (Aubl) Merr.) diketahui memiliki aktivitas antioksidan yang kuat sehingga berpotensi untuk dikembangkan menjadi sistem penghantaran nanopartikel. Penelitian ini bertujuan untuk mengetahui pengaruh variasi konsentrasi kitosan - tripolifosfat (TPP) terhadap karakteristik fisik dari nanopartikel. Ekstrak bawang dayak diformulasi dalam bentuk nanopartikel dengan metode gelasi ionik dengan variasi konsentrasi polimer kitosan : tripolifosfat yaitu $0,5 \%: 0,5 \%$ (F1), 0,75\%: $0,5 \%$ (F2), dan 1\%:0,5\% (F3). Parameter pengujian meliputi penentuan ukuran dan indeks polidispersitas nanopartikel menggunakan particle size analyzer, pengamatan morfologi menggunakan scanning electron microscopy, pengukuran efisiensi penjerapan, dan disolusi in vitro. Hasil penelitian menunjukkan bahwa nanopartikel F1, F2, dan F3 memiliki ukuran masing-masing sebesar 256,30 nm, 376,28 nm dan 419,18 nm dengan distribusi ukuran yang relatif homogen dan efisiensi penjerapan masing-masing sebesar $69,54 \%, 77,51 \%$ dan 79,79\%. Pengamatan morfologi dari nanopartikel menunjukkan bentuk partikel yang mendekati spheris (bulat) dengan permukaan yang kasar. Profil pelepasan obat dari nanopartikel F1, F2, dan F3 pada jam ke-8 masing-masing sebesar 71,19 \% (F1), 74,97\% (F2) dan 80,55\% (F3). Berdasarkan hasil penelitian yang telah dilakukan, dapat disimpulkan bahwa ekstrak bawang dayak dapat diformulasi dalam ukuran nanopartikel dengan karakteristik fisik yang bervariasi tergantung pada konsentrasi kitosan dan tripolifosfat yang digunakan.
\end{abstract}

Kata Kunci: Bawang dayak (Eleutherine americana (Aubl) Merr.), antioksidan, nanopartikel, kitosan, tripolifosfat, gelasi ionik.

\begin{abstract}
Bawang dayak (Eleutherine americana (Aubl) Merr.) ethanol extract had been known to have excellent antioxidant activity that has the potential to be developed into a nanoparticle delivery systems. This study aims to determine the effect of varying concentrations of chitosan - tripolyphosphate (TPP) to the physical characteristics of nanoparticles. Bawang dayak extract formulated in the form of nanoparticles with an ionic gelation method and and using polymers chitosan - tripolyphospate varying concentration as $0.5 \%: 0.5 \%(\mathrm{~F} 1), 0.75 \%$ : $0.5 \%(\mathrm{~F} 2)$, and $1 \%: 0.5 \%(\mathrm{~F} 3)$. The measured parameters were determinating particle size and polydispersity index using particle size analyzer, observation of particle morph using scanning electron microscopy, measurement of entrapment efficiency and dissolution in vitro. The result showed that the average size of nanoparticle F1, F2, and F3 respectively is $256.30 \mathrm{~nm}, 376 \mathrm{~nm}$ and $419.18 \mathrm{~nm}$ with entrapment efficiency respectively is $69.54 \%$ (F1),
\end{abstract}


$77.51 \%(\mathrm{~F} 2)$ and $79.79 \%(\mathrm{~F} 3)$ with a relatively homogenous size distribution and entrapment efficiencies respectively is $69.54 \%, 77.51 \%$ and $79.79 \%$. Observation of morphology of the nanoparticles shows the particle shape is almost sphere (spherical) with a rough surface. The profile of drug release from the nanoparticles F1, F2, and F3 in 8 hours respectively is $71.19 \%$ (F1), $74.97 \%$ (F2) and $80.55 \%$ (F3). Based on this study, it was concluded that the etanol extract of bawang dayak can be formulated into nanoparticles with different physical characteristics based on the ratio of polymer chitosan and tripolyphosphate used.

Keywords: Bawang dayak (Eleutherine americana (Aubl) Merr.), nanoparticles, chitosan, tripolyphosphate, ionic gelation.

\section{PENDAHULUAN}

Bawang dayak (Eleutherine americana (Aubl) Merr) secara tradisional telah digunakan sebagai antidiabetes (1), antiinflamasi (2), antimikroba (3), dan antikanker (4). Selain itu, bawang dayak (Eleutherine americana (Aubl) Merr) juga merupakan salah satu tanaman yang mengandung senyawa fenolik, flavonoid dan tanin yang memiliki aktivitas antioksidan yang kuat (5). Penilitian yang telah dilakukan sebelumnya menunjukkan bahwa ekstrak etanol 96\% umbi bawang dayak (Eleutherine americana (Aubl) Merr) yang berasal dari Malino, Kabupaten Gowa memiliki kandungan fenolik total sebesar $6,37 \% \mathrm{~b} / \mathrm{b}$ dan aktivitas antiradikal bebas yang tergolong kuat dengan nilai IC50 sebesar 22,63 $\mu \mathrm{g} / \mathrm{ml}$ (6). Sedangkan ekstrak etanol umbi bawang dayak (Eleutherine americana (Aubl) Merr.) yang berasal dari Banjarbaru memiliki nilai rata-rata IC50 sebesar 25,33 $\mu \mathrm{g} / \mathrm{mL}$ (2). Berdasarkan hal tersebut, bawang dayak memiliki potensi yang sangat besar untuk dijadikan sebagai bahan obat.

Dasar pertimbangan pada pengembangan teknologi untuk terapi farmasetis terdiri dari tiga faktor utama yaitu menciptakan sistem yang efektif (effectiveness), menekan efek bahaya pada sistem jika diaplikasikan (safety), dan membuat agar sistem dapat diterima dengan baik oleh pasien (acceptability). Maka dari itu, dikembangkan berbagai macam sistem penghantaran untuk obat dari bahan alam. Di antara berbagai jenis sistem penghantaran tersebut, para peneliti banyak menggunakan sistem penghantaran nanopartikel karena berbagai keuntungan antara lain yaitu ukuran partikel dan karakteristik permukaan nanopartikel dapat dengan mudah dimodifikasi sesuai kebutuhan, nanopartikel dapat mengontrol dan mempertahankan pelepasan senyawa aktif selama transportasi sehingga mengurangi efek samping, pelepasan senyawa aktif terkontrol, serta kandungan senyawa aktif dapat dimasukkan ke dalam sistem tanpa reaksi kimia yang menjadi faktor penting untuk menjaga aktivitas senyawa $(7,8)$.

Pembuatan nanopartikel dapat dilakukan dengan berbagai metode, salah satunya dengan metode gelasi ionik. Pada teknik gelasi ionik, dilakukan pencampuran antara polimer yang bersifat polikation dengan polianion. Polimer polikation yang umum digunakan adalah kitosan karena memiliki sifat yang tidak beracun, biocompatible, biodegradable dan mudah dimodifikasi secara kimia. Sedangkan polimer polianion yang umum digunakan adalah zat yang dapat berfungsi sebagai pengikat silang yang baik misalnya tripolifosfat (TPP). Dengan adanya penambahan TPP, kekuatan mekanik gel kitosan dapat meningkat sebab TPP memiliki rapatan muatan negatif yang tinggi sehingga interaksi dengan polikationik kitosan akan lebih besar $(9,10)$. Penelitian sebelumnya menunjukkan bahwa pembentukan nanopartikel dengan kitosan dan TPP sebagai polimer dapat menghasilkan 
nanopartikel dengan stabilitas yang baik (11). Konsentrasi polimer kitosan dan tripolifosfat (TPP) yang digunakan dapat mempengaruhi karateristik dari nanopartikel yang terbentuk $(12,13)$ dan juga mempengaruhi nilai dari efesiensi penjerapannya (14).

Tujuan penilitian adalah untuk mengetahui pengaruh variasi konsentrasi polimer kitosan - tripolifosfat (TPP) terhadap karakteristik fisik nanopartikel ekstrak bawang dayak (Eleutherine americana (Aubl) Merr).

\section{METODOLOGI PENELITIAN}

\subsection{Penyiapan Alat dan Bahan}

Alat-alat yang digunakan yaitu alat-alat gelas $\left(\right.$ Pyrex $\left.^{\circledR}\right)$, dissolution tester $\left(\right.$ Electrolab $\left.^{\circledR}\right)$, freeze dryer $\left(\right.$ CoolSafe $\left.{ }^{\mathrm{TM}}\right)$, homogenizer (Ultra Turrax ${ }^{\circledR}$ ), magnetic stirrer $\left(\right.$ IKA $^{\circledR}$ MIDI MR1), micropipet $\left(\right.$ Thermo $^{\circledR}$ ), oven (J.P.Selecta ${ }^{\circledR}$ ), Particle Size Analyzer (VASCO Flex ${ }^{\mathrm{TM}}$ ), $\mathrm{pH}$ meter (Sartorius ${ }^{\circledR}$ ), rotary evaporator $\left(\right.$ Buchi $\left.^{\circledR}\right)$, Scanning Electron Microscope $\left(\right.$ Tescan $\left.^{\circledR}\right)$, microplate reader $\left(\right.$ Biotec $\left.^{\circledR}\right)$, sonikator (Elmasonic ${ }^{\circledR}$ ), spektrofotometer UV-Vis (Shimadzu $^{\circledR}$ UV-1800) dan timbangan analitik (Sartorius ${ }^{\circledR}$ CP 224 S).

Bahan-bahan yang digunakan yaitu asam askorbat, asam asetat, asam galat, air suling, 2,2-difenil-1pikrilhidrazil (DPPH) (sigma aldrich $\left.{ }^{\circledR}\right)$, etanol 96\%, kalium dihidrogen fosfat, kitosan (sigma aldrich ${ }^{\circledR}$, natrium hidroksida, natrium karbonat, polysorbat 80 (bratako $\left.^{\circledR}\right)$, pereaksi folin-ciocalteu, natrium tripolifosfat $\left(\right.$ bratako $\left.^{\circledR}\right), \quad$ umbi bawang dayak (Eleutherine americana (Aubl) Merr).

\subsection{Metode Kerja}

\subsubsection{Penyiapan Sampel Penelitian}

Sampel penelitian yang digunakan adalah umbi bawang dayak
(Eleutherine americana (Aubl) Merr) yang diperoleh dari Malino, Kabupaten Gowa, Provinsi Sulawesi Selatan.

\subsubsection{Pengolahan Sampel}

Sampel berupa umbi bawang dayak, dicuci bersih dengan air mengalir. Sampel yang sudah bersih dikupas-kupas kecil dan dikeringkan pada oven simplisia pada suhu $50^{\circ} \mathrm{C}$. Sampel yang telah kering kemudian dirajang.

\subsubsection{Ekstraksi Sampel}

Ekstraksi dilakukan dengan cara maserasi dan dibantu dengan proses sonikasi selama 30 menit menggunakan pelarut etanol $96 \%$. Simplisia umbi bawang dayak (Eleutherine americana (Aubl) Merr) dimasukkan ke dalam wadah maserasi bersama cairan etanol $96 \%$, kemudian ditutup rapat. Wadah maserasi dimasukkan ke dalam sonikator dan disonikasi selama 30 menit, ekstrak yang diperoleh dipisahkan dan dilakukan remaserasi menggunakan pelarut yang sama. Ekstrak cair yang diperoleh dari tiap-tiap proses ekstraksi dikumpulkan, kemudian diuapkan cairan penyari dengan menggunakan rotary evaporation hingga didapatkan ekstrak kental.

\subsubsection{Penentuan Kadar Fenolik Total}

\subsubsection{Pembuatan Larutan Stok Asam Galat}

Ditimbang asam galat sebanyak $10 \mathrm{mg}$ lalu dilarutkan dengan dapar fosfat $\mathrm{pH}$ 7,4 hingga $10 \mathrm{ml}$ (konsentrasi 1000 bpj). Kemudian dari larutan tersebut, dipipet sebanyak $1 \mathrm{ml}$ dan dicukupkan volumenya hingga $10 \mathrm{ml}$ dengan dapar fosfat $\mathrm{pH}$ 7,4 (konsentrasi $100 \mathrm{bpj}$ ).

\subsubsection{Penentuan Panjang Gelombang Maksimum Asam Galat}

Sebanyak $0,25 \mathrm{ml}$ larutan stok asam galat dipipet dan dicukupkan 
volumenya hingga $5 \mathrm{ml}$ dalam labu tentukur. Kemudian ditambahkan $0,1 \mathrm{ml}$ pereaksi Folin-Ciocalteau dan $0,1 \mathrm{ml}$ $\mathrm{Na}_{2} \mathrm{CO}_{3} \quad 7,5 \%$, dihomogenkan lalu dicukupkan volumenya hingga $5 \mathrm{ml}$ dengan dapar fosfat $\mathrm{pH}$ 7,4. Campuran tersebut dibiarkan selama 30 menit. Kemudian serapannya diukur pada panjang gelombang 400-800 $\mathrm{nm}$.

\subsubsection{Pembuatan Kurva Baku Asam} Galat

Dibuat satu seri larutan asam galat dengan konsentrasi 1,2, 3, 4, 5, 6 dan 7 bpj, dengan cara dipipet larutan stok masing-masing sebanyak 50, 100, 150, 200, 250, 300 dan $350 \mu 1$, dimasukkan ke dalam labu tentukur, kemudian ditambahkan $0,1 \mathrm{ml}$ pereaksi FolinCiocalteau dan $0,1 \mathrm{ml} \mathrm{Na} \mathrm{CO}_{3} 7,5 \%$ lalu dicukupkan volumenya hingga $5 \mathrm{ml}$ dengan dapar fosfat $\mathrm{pH} \mathrm{7,4.} \mathrm{Campuran}$ tersebut didiamkan selama 30 menit, kemudian diukur serapannya pada panjang gelombang serapan maksimum, kemudian dibuat kurva baku hubungan antara konsentrasi asam galat dengan serapan.

\subsubsection{Pembuatan Larutan Stok Ekstrak}

Ekstrak bawang dayak ditimbang sebanyak $10 \mathrm{mg}$, kemudian dilarutkan dengan $1 \mathrm{ml}$ etanol $96 \%$ dan dicukupkan volumenya hingga $10 \mathrm{ml}$ dalam labu tentukur dengan larutan dapar fosfat $\mathrm{pH}$ 7,4 , sehingga diperoleh larutan stok 1000 bpj.

\subsubsection{Pengujian Kadar Fenolik Total}

Sebanyak 0,3 ml larutan ektsrak dipipet dari larutan stok dan ditambahkan sebanyak $0,1 \mathrm{ml}$ pereaksi FolinCiocalteau dan $0,1 \mathrm{ml} \mathrm{Na}_{2} \mathrm{CO}_{3} 7,5 \%$, kemudian volume dicukupkan hingga 5 $\mathrm{ml}$ dalam labu tentukur dengan larutan dapar fosfat $\mathrm{pH} \quad 7,4$ dan campuran didiamkan selama 30 menit pada suhu kamar (suhu $15-30^{\circ} \mathrm{C}$ ). Setelah itu, ditetapkan kadarnya dengan mengukur serapannya pada panjang gelombang maksimum 673,6 nm menggunakan spektrofotometer UV-Vis. Kemudian dihitung kadar fenolik total dari sampel dengan bantuan kurva baku. Kadar fenolik total dinyatakan sebagai sejumlah $\mathrm{mg}$ ekivalen asam galat (EAG)/g sampel.

\subsubsection{Penentuan Kadar Antioksidan}

\subsubsection{Pembuatan Larutan 2,2-Difenil- 1-Pikrilhidrazil (DPPH) $240 \boldsymbol{\mu M}$ \\ DPPH (394,32 g/mol) ditimbang} sebanyak $1 \mathrm{mg}$, kemudian dilarutkan dalam etanol p.a hingga volume $10 \mathrm{ml}$ dalam labu tentu ukur.

\subsubsection{Pembuatan Larutan Stok Ekstrak}

Ekstrak umbi bawang dayak ditimbang sebanyak $10 \mathrm{mg}$, kemudian dilarutkan dengan $1 \mathrm{ml}$ etanol $96 \%$ dan dicukupkan volumenya hingga $10 \mathrm{ml}$ dalam labu tentukur dengan etanol p.a (konsentrasi 1000 bpj).

\subsubsection{Pengujian Aktivitas Antioksidan Sampel}

Larutan stok ekstrak masingmasing dipipet sebanyak $4 \mu \mathrm{l}, 8 \mu \mathrm{l}, 12 \mu \mathrm{l}$, $16 \mu 1$ dan $20 \mu 1$ ke dalam microplate, lalu masing-masing ditambahkan $75 \mu \mathrm{l}$ DPPH $240 \mu \mathrm{M}$ dengan menggunakan mikropipet multichannel dan volume campuran dicukupkan sehingga $200 \mu \mathrm{l}$ dengan pelarut etanol p.a, sehingga didapatkan seri konsentrasi 20 bpj, 40 bpj, 60 bpj, 80 bpj dan 100 bpj. Campuran tersebut diinkubasi pada suhu $37^{\circ} \mathrm{C}$ selama 30 menit, kemudian diukur absorbansinya pada panjang gelombang maksimum 515 $\mathrm{nm}$ dengan menggunakan microplate reader, sebagai blanko larutan DPPH 240 
$\mu \mathrm{M}$ dipipet sebanyak $75 \mu \mathrm{l}$ kemudian ditambahkan $125 \mu$ l etanol p.a. Untuk pembanding digunakan asam askorbat dengan konsentrasi 2,5 bpj, $5 \mathrm{bpj}, 7,5 \mathrm{bpj}$, 10 bpj dan 12,5 bpj. Aktivitas antioksidan dari masing-masing sampel dinyatakan dengan persen inhibisi, dan dihitung dengan rumus yaitu:
$\%$ inhibisi $=\frac{\text { serapan blanko }- \text { serapan sampel }}{\text { serapan blanko }} \times 100 \%$

Persen inhibisi yang dihasilkan oleh masing-masing konsentrasi ekstrak umbi bawang dayak, kemudian ditabulasi dan dihitung nilai $\mathrm{IC}_{50}$.

\subsubsection{Preparasi Nanopartikel Ekstrak Bawang Dayak}

Tabel 1. Formula nanopartikel ekstrak bawang dayak

\begin{tabular}{lccc}
\multicolumn{1}{c}{ Bahan } & F1 & F2 & F3 \\
\hline Ekstrak Bawang Dayak & $1000 \mathrm{mg}$ & $1000 \mathrm{mg}$ & $1000 \mathrm{mg}$ \\
Larutan Kitosan 0,5\% & $100 \mathrm{ml}$ & - & - \\
Larutan Kitosan 0,75\% & - & $100 \mathrm{ml}$ & - \\
Larutan Kitosan 1 \% & - & - & $100 \mathrm{ml}$ \\
Larutan TPP 0,5 \% & $20 \mathrm{ml}$ & $30 \mathrm{ml}$ & $40 \mathrm{ml}$ \\
Polysorbat 80 & $1 \mathrm{ml}$ & $1 \mathrm{ml}$ & $1 \mathrm{ml}$ \\
\hline
\end{tabular}

\subsubsection{Pembuatan Larutan Kitosan}

Kitosan ditimbang masingmasing sebanyak 0,5 gram, 0,75 gram dan 1 gram dengan menggunakan kaca arloji, kemudian kitosan dilarutkan dengan larutan asam asetat $5 \% \mathrm{v} / \mathrm{v}$ hingga $100 \mathrm{ml}$ dan diaduk dengan pengaduk magnetik hingga larut.

\subsubsection{Pembuatan larutan TPP}

Tripolifosfat (TPP) ditimbang masing-masing sebanyak 0,1 gram, 0,15 gram dan 0,2 gram kemudian dilarutkan masing-masing dengan air suling hingga $20 \mathrm{ml}, 30 \mathrm{ml}$, dan $40 \mathrm{ml}$ kemudian diaduk dengan pengaduk magnetik hingga larut.

\subsubsection{Penyiapan Ekstrak Umbi Bawang Dayak}

Sebanyak 0,1 gram ekstrak umbi bawang dayak ditimbang dan dilarutkan dalam etanol $96 \%$ sebanyak $5 \mathrm{ml}$ dan dilakukan sonikasi selama 10 menit.

\subsubsection{Pembuatan Nanopartikel Ekstrak Bawang Dayak}

Masing-masing larutan kitosan $0,5 \%, 0,75 \%$ dan $1 \%$ dimasukkan ke dalam gelas kimia sebanyak $100 \mathrm{ml}$. Kemudian pada masing-masing konsentrasi larutan ditambahkan polysorbat 80 sebanyak $1 \mathrm{ml}$ dan diaduk dengan menggunakan homogenizer dengan kecepatan $1000 \mathrm{rpm}$ selama 10 menit. Setelah itu, pada larutan kitosan 0,5 $\%, 0,75 \%$ dan $1 \%$ dimasukkan masingmasing 0,1 g ekstrak bawang dayak (Eleutherine americana (Aubl) Merr) dan diaduk dengan menggunakan homogenizer dengan kecepatan $3000 \mathrm{rpm}$ selama 30 menit. Setelah itu, kedalam larutan kitosan 0,5\%,0,75\% dan $1 \%$ masing-masing ditambahkan larutan TPP $0,5 \%$ sebanyak $20 \mathrm{ml}, 30 \mathrm{ml}$ dan $40 \mathrm{ml}$, lalu dihomogenizer pada kecepatan 4000 rpm selama 90 menit. Campuran yang diperoleh kemudian didiamkan selama $1 \mathrm{x}$ 24 jam dan kemudian diliofilisasi (freezedrying) untuk mendapatkan nanopartikel 
kering dan diuji karakterisasinya dengan Particle Size Analyzer (PSA) dan Scanning Electron Microscope (SEM).

\subsubsection{Pengukuran Efesiensi Penjerapan} Nanopartikel yang diperoleh juga dianalisis secara kuantitatif kandungan polifenol totalnya untuk menentukan efisiensi penjerapan dari nanopartikel. Nanopartikel ekstrak umbi bawang dayak dari ketiga formula, masing-masing ditimbang seksama setara dengan sebanyak $10 \mathrm{mg}$ ekstrak kemudian masing-masing dilarutkan dengan $1 \mathrm{ml}$ etanol $96 \%$ dan dicukupkan volumenya hingga $10 \mathrm{~mL}$ dengan larutan dapar fosfat pH 7,4 (1000 bpj). Selanjutnya masingmasing diambil 0,3 $\mathrm{ml}$ dari larutan stok, ditambahkan $0,1 \mathrm{ml}$ pereaksi FolinCiocalteau dan $0,1 \mathrm{ml} \mathrm{Na}_{2} \mathrm{CO}_{3} \quad 7,5 \%$ kemudian dicukupkan volumenya dengan larutan dapar fosfat $\mathrm{pH}$ 7,4 sampai $5 \mathrm{~mL}$ dan dihomogenkan. Campuran tersebut didiamkan selama 30 menit kemudian ditetapkan kadarnya dengan mengukur serapannya pada panjang gelombang maksimum 673,6 nm menggunakan spektrofotometer UV-Vis. Efisiensi penjerapan nanopartikel dihitung dengan menggunakan rumus sebagai berikut :

$$
E p(\%)=\frac{\text { Kadar fenolik nanopartikel }}{\text { Kadar fenolik ekstrak }} \times 100 \%
$$

\subsubsection{Evaluasi Nanopartikel Ekstrak Bawang Dayak}

\subsubsection{Pengukuran pH}

Pengukuran $\mathrm{pH}$ dilakukan dengan menggunakan $\mathrm{pH}$ meter dengan cara mencelupkan elektroda ke dalam suspensi nanopartikel F1, F2 dan F3.

\subsubsection{Morfologi Partikel}

Nanopartikel yang dihasilkan, dikarakterisasi dengan menggunakan instrumen Scanning Electron Microscope
(Vega3 Tescan ${ }^{\circledR}$ ). Nanopartikel ekstrak bawang dayak (Eleutherine americana (Aubl) Merr) di coating dengan logam emas menggunakan fine coater $\left(\right.$ Quantum ${ }^{\circledR}$ ) di bawah vakum. Sampel kemudian diuji dan diamati bentuk partikel dan permukaannya.

\subsubsection{Ukuran Partikel}

Ukuran partikel dari nanopartikel ekstrak bawak dayak (Eleutherine americana (Aubl) Merr) diukur dengan menggunakan alat Particle Size Analyzer (VASCO Flex ${ }^{T M}$ ).

\subsubsection{Uji Disolusi In Vitro}

Sebanyak 0,5 gram nanopartikel ekstrak bawang dayak (Eleutherine americana (Aubl) Merr) di disolusi dalam $900 \mathrm{~mL}$ larutan dapar fosfat $\mathrm{pH} \quad 7,4$ menggunakan alat disolusi tipe 2 pada suhu $37 \pm 0,5^{\circ} \mathrm{C}$, dengan kecepatan putaran pengadukan adalah $100 \mathrm{rpm}$ selama 8 jam. Sebanyak $10 \mathrm{ml}$ alikuot dicuplik pada menit ke- 30, 60, 120, 240, dan 480. Setiap kali pengambilan alikuot, volume medium yang terambil (dapar fosfat $\mathrm{pH} \quad 7,4$ ) digantikan dengan larutan medium yang baru dengan volume dan suhu yang sama. Masing-masing alikuot disaring dan sampel dianalisa menggunakan metode spektrofotometri UV pada panjang gelombang maksimum $673,6 \mathrm{~nm}$.

\section{HASIL DAN PEMBAHASAN}

\subsection{Kadar Fenolik Total Ekstrak Bawang Dayak \\ Ekstrak bawang dayak mengandung fenolik total (setara asam galat) sebesar $7,77 \% \mathrm{~b} / \mathrm{b}$.}




\subsection{Aktivitas Antioksidan Ekstrak Bawang Dayak \\ Pengujian aktivitas antioksidan} ekstrak umbi bawang dayak menggunakan metode DPPH (1,1- Diphenyl-2Picryhydrazyl). Hasil menunjukkan semakin rendah nilai serapan yang terukur maka semakin tinggi aktivitas penghambatan radikal bebasnya. Aktivitas penjerapan DPPH dari ekstrak umbi bawang dayak dapat dilihat pada tabel 4 dan 5, yaitu nilai $\mathrm{IC}_{50}$ dari ekstrak umbi bawang dayak dan asam askorbat masing-masing adalah sebesar 25,66 $\mu \mathrm{g} / \mathrm{ml}$ dan $3,70 \mu \mathrm{g} / \mathrm{ml}$.

Tabel 2. Aktivitas antioksidan ekstrak bawang dayak

\begin{tabular}{ccccc}
\hline $\begin{array}{c}\text { Konsentrasi } \\
(\mathbf{b p j})\end{array}$ & $\begin{array}{c}\text { Log } \\
\text { konsentrasi }\end{array}$ & $\begin{array}{c}\text { \% inhibisi } \pm \\
\text { SD }^{*}\end{array}$ & $\begin{array}{c}\text { Nilai probit } \pm \\
\text { SD* }\end{array}$ & $\begin{array}{c}\text { IC50 } \\
(\boldsymbol{\mu g} / \mathbf{m l})\end{array}$ \\
\hline 20 & 1,30 & $41,79 \pm 0,28$ & $4,76 \pm 0,01$ & \\
40 & 1,60 & $64,11 \pm 0,27$ & $5,36 \pm 0,01$ & \\
60 & 1,77 & $73,58 \pm 0,05$ & $5,63 \pm 0,00$ & 25,66 \\
80 & 1,90 & $78,67 \pm 0,21$ & $5,79 \pm 0,01$ & \\
100 & 2,00 & $83,14 \pm 0,41$ & $5,96 \pm 0,02$ & \\
\hline
\end{tabular}

$* \overline{\mathrm{SD}}=$ Standar Deviasi

Tabel 3. Aktivitas antioksidan asam askorbat (kontrol postif)

\begin{tabular}{ccccc}
\hline $\begin{array}{c}\text { Konsentrasi } \\
(\mathbf{b p j})\end{array}$ & $\begin{array}{c}\text { Log } \\
\text { konsentrasi }\end{array}$ & $\begin{array}{c}\text { \% inhibisi } \pm \\
\text { SD }^{*}\end{array}$ & $\begin{array}{c}\text { Nilai probit } \pm \\
\text { SD }^{*}\end{array}$ & $\begin{array}{c}\text { IC50 } \\
(\boldsymbol{\mu g} / \mathbf{m l})\end{array}$ \\
\hline 2,5 & 0,39 & $28.563 \pm 2,86$ & $4,43 \pm 0,08$ & \\
5 & 0,69 & $64.563 \pm 1,47$ & $5,38 \pm 0,03$ & \\
7,5 & 0,87 & $86.170 \pm 1,62$ & $6,09 \pm 0,07$ & 3,70 \\
10 & 1,00 & $90.183 \pm 0,39$ & $6,29 \pm 0,02$ & \\
12,5 & 1,09 & $90.563 \pm 0,52$ & $6,39 \pm 0,02$ & \\
\hline
\end{tabular}

$* \overline{\mathrm{SD}}=$ Standar Deviasi

Hasil analisis statistik ANOVA satu arah menunjukkan bahwa ada perbedaan nyata $(\alpha<0,01)$ antara nilai $\mathrm{IC}_{50}$ ekstrak bawang dayak dengan nilai $\mathrm{IC}_{50}$ kontrol positif asam askorbat.

\subsection{Evaluasi Nanopartikel Ekstrak Bawang Dayak}

Pada penelitian ini dibuat tiga jenis formula nanopartikel dengan variasi konsentrasi kombinasi polimer kitosan dan tripolifosfat. Pencampuran polimer kitosan dan tripolifosfat akan menghasilkan interaksi antara muatan positif pada gugus amino kitosan dengan muatan negatif dari tripolifosfat. Dimana konsentrasi antara polimer kitosan dan tripolifosfat yang digunakan dapat mempengaruhi katrakteristik fisik dari nanopartikel.

Variasi

perbandingan

konsentrasi antara kitosan dan tripolifosfat (TPP) yang digunakan sebagaimana pada metodologi yaitu kitosan $0,5 \%$ dan TPP $0,5 \%$ yang dinyatakan sebagai formula F1, kitosan $0,75 \%$ dan TPP $0,5 \%$ sebagai F2, kitosan $1 \%$ dan TPP $0,5 \%$ sebagai F3. Penggunaan rasio $5: 1$ antara berat kitosan dan TPP didasarkan pada penelitian oleh Zhang (2004) bahwa dengan meningkatkan rasio kitosan dan TPP, akan dihasilkan nanopartikel dengan ukuran yang lebih kecil. Dimana rasio optimal antara kitosan dan TPP adalah 5:1 b/b, yang mungkin berkaitan dengan fakta 
bahwa TPP adalah poli-fungsional agen cross-linking dan dapat menciptakan lima ikatan silang ionik dengan gugus amin dari kitosan. Rasio Kitosan : TPP (5:1) juga menghasilkan efisiensi penjerapan paling baik dan dan nanopartikel dengan struktur partikel kompak (15).

Karakteristik fisik dari nanopartikel bawang dayak diuji dengan penentuan ukuran nanopartikel yang diukur menggunakan Particle Size Analyzer (PSA) dan hasil morfologi partikel dengan menggunakan Scanning Electron Microscopy (SEM). Dari data diketahui bahwa ukuran partikel dari ketiga formula yang diperoleh menunjukkan bahwa ukuran partikel dari nanopartikel ekstrak bawang dayak F1, F2, dan F3 berturut-turut adalah 256,30 $\mathrm{nm}, \quad 376,28 \mathrm{~nm}$ dan 419,18 nm. Secara umum dari ketiga hasil masih memasuki rentang ukuran nanopartikel yaitu 10$1000 \mathrm{~nm}$ (16). Data mengenai ukuran partikel ini sesuai dengan penelitian Calvo, dkk (1997) bahwa nanopartikel kitosan - tripolifosfat yang dibuat dengan metode gelasi ionik menghasilkan ukuran partikel antara 200-500 nm (17).

Dari hasil penelitian yang ditampilkan pada gambar 8 diketahui bahwa ada keterkaitan antara konsentrasi kitosan dan tripolifosfat yang digunakan dengan ukuran nanopartikel yang terbentuk. Semakin besar konsentrasi kitosan dan tripolifosfat yang digunakan maka semakin besar pula ukuran partikel yang dihasilkan (18).

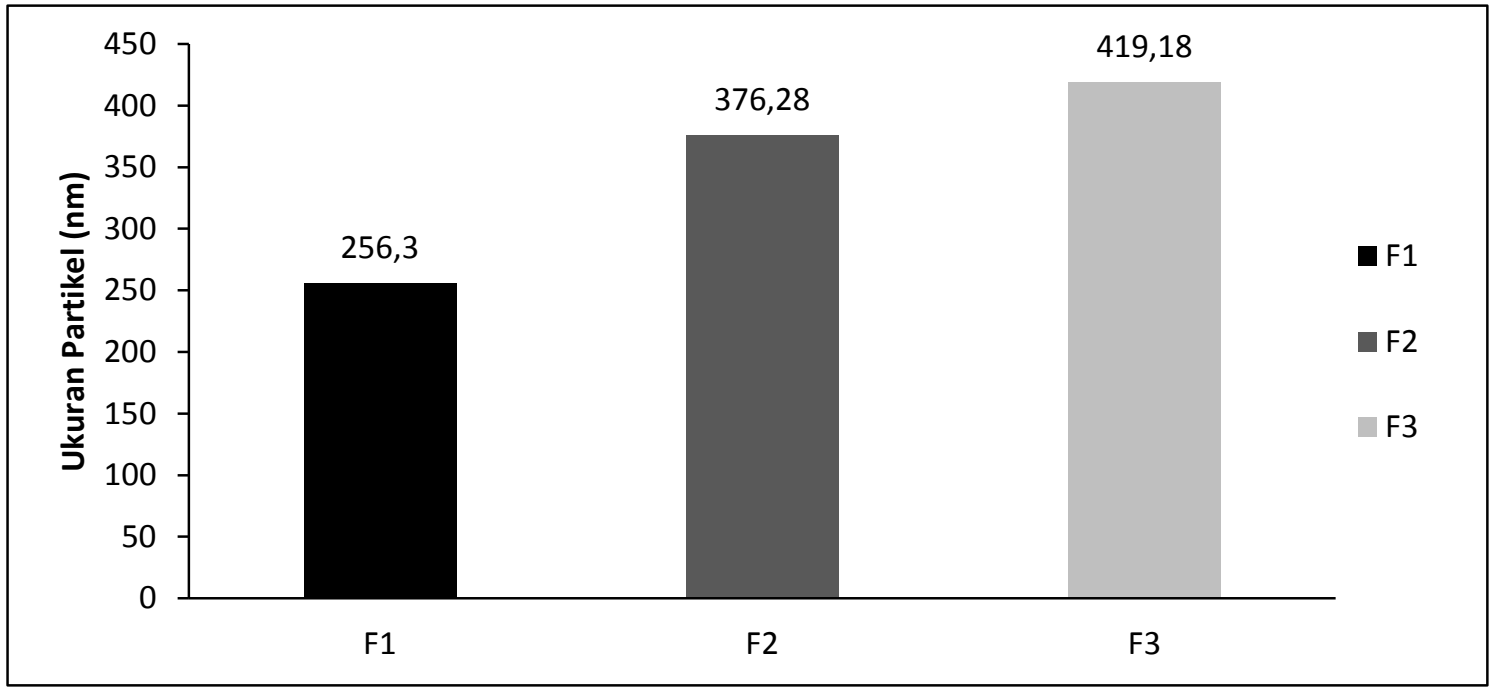

Gambar 1. Grafik ukuran partikel dari nanopartikel F1 (Kitosan 0,5\% dan TPP 0,5\%), F2(Kitosan 0,75\% dan TPP 0,5\%), dan F3 (Kitosan 1\% dan TPP 0,5\%)

Faktor lainnya yang mempengaruhi ukuran nanopartikel adalah $\mathrm{pH}$. Perbedaan $\mathrm{pH}$ berpengaruh pada jumlah ion amin yang akan terprotonasi. Pada pembuatan nanopartikel, dapat dilihat bahwa semakin tinggi konsentrasi kitosan yang digunakan maka $\mathrm{pH}$ yang dihasilkan semakin kecil dan semakin besar pula ukuran partikel yang dihasilkan. Hal ini sesuai dengan penelitian yang dilakukan oleh Hui liu (2008) yang menunjukkan bahwa besar $\mathrm{pH}$ sangat mempengaruhi ukuran dari nanopartikel. Pada rentang $\mathrm{pH}$ 3,5-5,5 ukuran nanopartikel semakin kecil seiring dengan semakin tingginya nilai $\mathrm{pH}$ (19).

Distribusi ukuran partikel dinyatakan dalam indeks polidispersitas. 
Hasil indeks polidispersitas dari nanopartikel F1, F2, dan F3 adalah 0,$2570 ; 0,3420$; dan 0,2880. Hasil dari ketiga formula ini memiliki indeks polidispersitas sekitar $0,2-0,3$ sehingga ketiga formula menunjukkan dispersi ukuran yang relatif homogen.

Tabel 4. Ukuran dan indeks polidispersitas dari nanopartikel ekstrak bawang dayak

\begin{tabular}{lccc}
\hline Sampel & pH & $\begin{array}{c}\text { Ukuran partikel } \\
(\mathbf{n m})\end{array}$ & $\begin{array}{c}\text { Indeks } \\
\text { Polidispersitas }\end{array}$ \\
\hline F1 (Kitosan 0,5\% dan TPP 0,5\%) & 5,02 & 256,30 & 0,2570 \\
F2 (Kitosan 0,75\% dan TPP 0,5\%) & 4,54 & 376,28 & 0,3420 \\
F3 (Kitosan 1 \% dan TPP 0,5\%) & 3,97 & 419,18 & 0,2880 \\
\hline
\end{tabular}

Hasil morfologi partikel yang diamati menggunakan Scanning Electron Microscopy (SEM) menunjukkan bahwa nanopartikel ekstrak bawang dayak dari ketiga formula memiliki permukaan yang kasar. Permukaan yang kasar tersebut kemungkinan disebabkan oleh proses coating dengan logam emas yang kurang baik pada saat preparasi sampel untuk pengujian dengan Scanning Electron Microscopy (SEM).
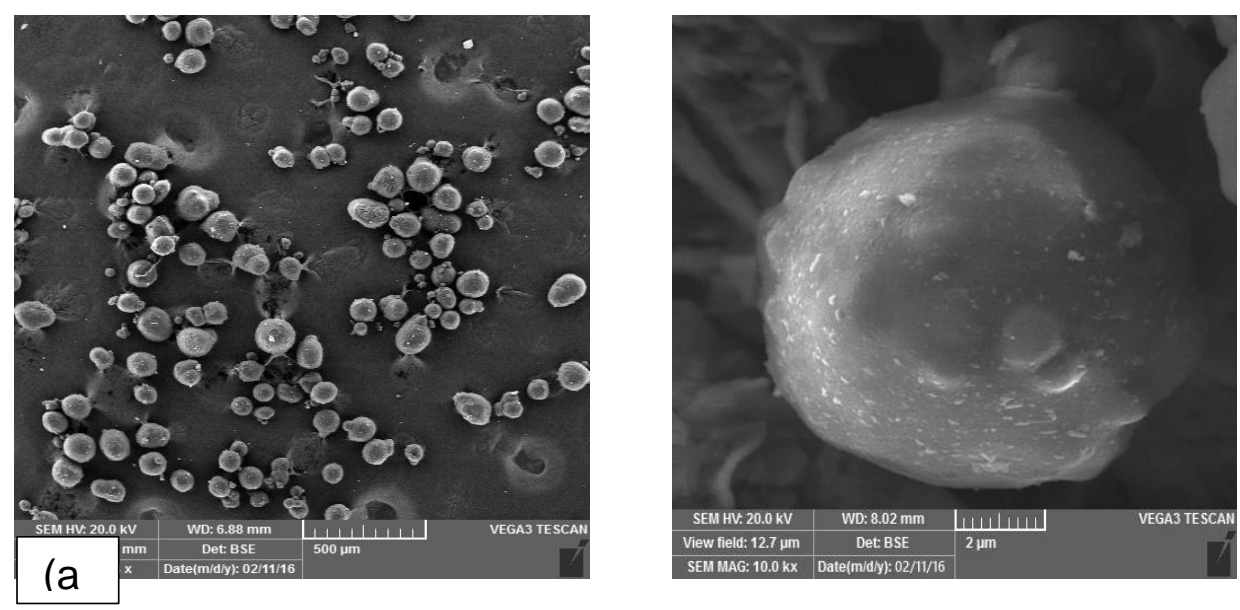

Gambar 2. Hasil SEM Morfologi Nanopartikel F1 (a) perbesaran 500x (b) perbesaran $10000 x$ 

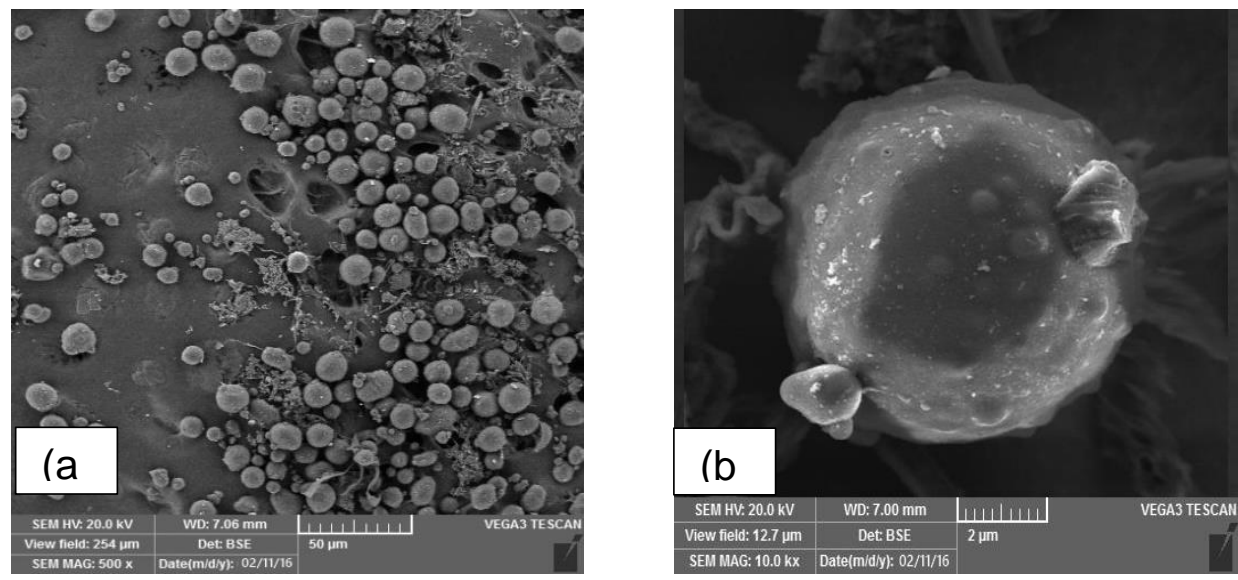

Gambar 3. Hasil SEM Morfologi Nanopartikel F2 (a) perbesaran 200x (b) perbesaran 10000x
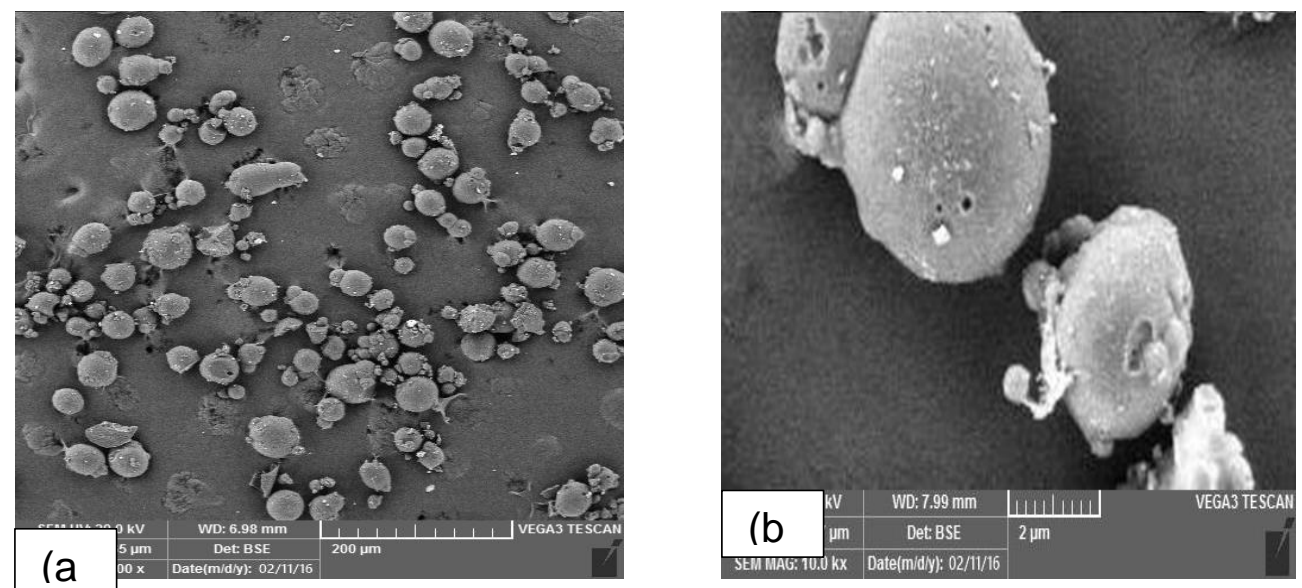

Gambar 4. Hasil SEM Morfologi Nanopartikel F3 (a) perbesaran 200x (b) perbesaran 10000x

Evaluasi lainnya yang dilakukan adalah pengukuran efisiensi penjerapan dari nanopartikel dengan tujuan untuk mengetahui gambaran tentang jumlah obat yang berhasil terperangkap / diserap kedalam nanopartikel. Berdasarkan hasil pengukuran efisiensi penjerapan dari ketiga formula, F3 memiliki efisiensi penjerapan yang paling tinggi kemudian F2, sedangkan F1 menunjukkan efisiensi penjerapan yang paling rendah. Hasil penelitian menunjukkan bahwa semakin tinggi jumlah polimer yang digunakan, maka semakin tinggi juga efisiensi penjerapan dari nanopartikel. 
Tabel 5. Efisiensi penjerapan dari nanopartikel ekstrak bawang dayak

\begin{tabular}{lcc}
\hline Sampel & $\begin{array}{c}\text { Kadar Fenolik Total } \\
(\mathbf{\% b} / \mathbf{b}) \pm \text { SD }\end{array}$ & $\begin{array}{c}\text { Efesiensi Penjerapan } \\
(\boldsymbol{\%}) \pm \text { SD }\end{array}$ \\
\hline F1 (Kitosan 0,5\% dan TPP 0,5\%) & $5,40 \pm 0,30$ & $69,54 \pm 3,16$ \\
F2 (Kitosan 0,75\% dan TPP 0,5\%) & $5,97 \pm 0,02$ & $77,51 \pm 0,26$ \\
F3 (Kitosan 1\% dan TPP 0,5\%) & $6,20 \pm 0,05$ & $79,79 \pm 0,52$ \\
\hline
\end{tabular}

*SD = Standar Deviasi

Selanjutnya, dilakukan uji disolusi terhadap nanopartikel ekstrak bawang dayak dengan mengunakan medium dapar fosfat $\mathrm{pH} 7,4$ dan dilakukan pencuplikan sebanyak $10 \mathrm{ml}$ pada waktu disolusi 0,5 jam, 1 jam, 2 jam, 4 jam dan 8 jam.

Tabel 6. Persen disolusi nanopartikel ekstrak bawang dayak

\begin{tabular}{cccccc}
\hline \multicolumn{2}{c}{ FORMULA 1 } & \multicolumn{2}{c}{ FORMULA 2 } & \multicolumn{2}{c}{ FORMULA 3 } \\
\hline $\begin{array}{c}\text { Waktu } \\
\text { (jam) }\end{array}$ & $\begin{array}{c}\text { \% Disolusi } \pm \\
\text { SD }\end{array}$ & $\begin{array}{c}\text { Waktu } \\
\text { (jam) }\end{array}$ & $\begin{array}{c}\text { \% Disolusi } \pm \\
\text { SD }\end{array}$ & $\begin{array}{c}\text { Waktu } \\
\text { (jam) }\end{array}$ & $\begin{array}{c}\text { \% Disolusi } \pm \\
\text { SD }\end{array}$ \\
\hline 0.5 & $26,32 \pm 1,57$ & 0.5 & $28,71 \pm 1,90$ & 0.5 & $30,61 \pm 1,19$ \\
1 & $32,06 \pm 1,84$ & 1 & $32,29 \pm 1,45$ & 1 & $34,85 \pm 1,50$ \\
2 & $37,05 \pm 0,21$ & 2 & $40,47 \pm 2,10$ & 2 & $46,66 \pm 0,91$ \\
4 & $61,81 \pm 2,04$ & 4 & $61,27 \pm 0,40$ & 4 & $68,71 \pm 2,01$ \\
8 & $71,19 \pm 1,11$ & 8 & $74,97 \pm 0,30$ & 8 & $80,55 \pm 1,42$ \\
\hline
\end{tabular}

*SD = Standar Deviasi

Hasil uji disolusi dari tiap formula dapat dilihat pada gambar 5 dan hasilnya menunjukkan bahwa nanopartikel F3 dengan konsentrasi polimer yang paling besar menunjukkan profil pelepasan lebih besar dibanding dengan F1 ataupun F2. Sifat kimia dan fisik dari polimer diketahui mempengaruhi profil pelepasan dari obat. Berdasarkan penelitian yang dilakukan oleh Dunne (2000) diketahui bahwa partikel dengan ukuran yang lebih besar akan memberikan kontribusi untuk polimer penyalut lebih cepat mengalami degradasi yang menyebabkan semakin besarnya juga pelepasan obat (20). 


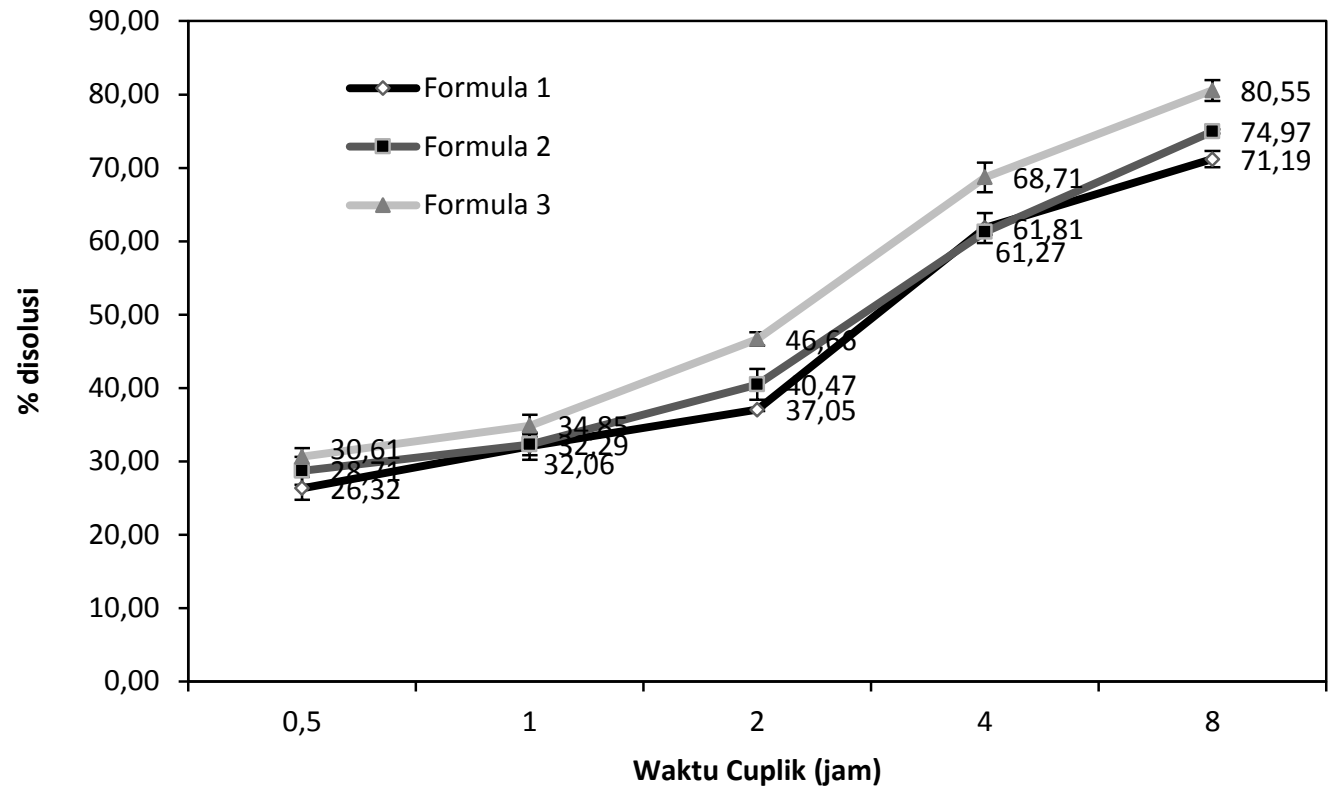

Gambar 5. Grafik persen disolusi nanopartikel F1, F2, dan F3

\section{KESIMPULAN}

Berdasarkan hasil penelitian yang telah dilakukan, dapat disimpulkan bahwa ekstrak bawang dayak dapat diformulasi dalam ukuran nanopartikel dengan karakteristik fisik yang bervariasi tergantung pada konsentrasi kitosan dan tripolifosfat yang digunakan.

\section{DAFTAR PUSTAKA}

1. Febrinda AE, Astawan M, Wresdiyati $\mathrm{T}$ dan Yuliana ND. Kapasistas antioksidan dan inhibitor alfa glucosidase ekstrak umbi bawang dayak. Jurnal teknologi dan Industri Pangan. 2013. 24 (2); pp. 161-167.

2. Kuntorini EM, Astuti MD. Penentuan Aktivitas Antioksidan Ekstrak Etanol Bulbus Bawang Dayak (Eleutherine americana Merr). Sains dan Terapan Kimia. 2010. 4 (1); pp. 15 - 22.

3. Ifesan B, Ibrahim D dan Voravuthikunchai SP. Antimicrobial
Activity of Crude Ethanolic Extract From Eleutherine americana. Journal of Food, Agriculture \& Environment. 2010. 8 (3 \& 4); pp. 1233-1236.

4. Fitri Y, Rosidah dan Suwarso E. Effects of inhibition cell cycle an apoptosis of sabrang onion extract (Eleuthetine bulbosa (Mill.) Urb.) on breast cancer cells. International Journal of PharmTech Research. 2014. 6 (4); pp. 1392-1396.

5. Pratiwi D, Wahdaningsih S, Isnindar. The Test of Antioxidant Activity from Bawang Mekah Leaves (Eleutherine americana Merr.) using DPPH (2,2Diphenyl-1-Picrylhydrazyl) Method. Traditional Medicine Journal. 2013. 18 (1); pp. 9-16.

6. Ridwan I. Pengaruh Konsentrasi Cairan Penyari Etanol Terhadap Kadar Fenolik Total Dan Aktivitas Antioksidan Ekstrak Umbi Bawang Dayak (Eleutherine americana (Aubl) Merr). Skripsi Program Studi Farmasi 
Fakultas Farmasi Universitas Hasanuddin. Makassar. 2015.

7. Martien R, Adhyatmika, Iramie DK, Farida V, Purwita SD. Perkembangan Teknologi Nanopartikel Sebagai Sistem Penghantaran Obat. Majalah Farmaseutik. 2012. 8(1); pp. 133-144.

8. Dewandari KT, Yuliani S, Yasni S. Ekstraksi dan Karakterisasi Nanopartikel Ekstrak Sirih Merah (Piper crocatum). Jurnal Pascapanen. 2013. 10(2); pp. 58-65.

9. Kaban J, Bangun HD, Asteria KD. Pembuatan Membran Kompleks Polielektrolit Alginat Kitosan. Jurnal Sains Kimia. 2006. 10 (1); pp. 10-16.

10. Shu XZ, Zhu KJ. Controlled Drug Release properties of ionically Crosslinked chitosan beads : The influence of anion structure. International Journal of Pharmaceutics. 2002. 233 (1-2); pp. 217-255.

11. Liu H, Gao C. Preparation and properties of ionically cross-linked chitosan nanoparticles. Polymers for Advance Technologies. 2009. 20 (7); pp. 613-619.

12. Wang N, Zhang M. Chitosan-Based Hydrogels for Controlled, Localized Drug Delivery. Advanced Drug Delivery Review. 2010.9 (1); pp. 8399.

13. Anggasari N, Alauhdin M, Tri AP, Sintesis dan Karakterisasi Membran Kitosan-Tripolifosfat sebagai Alternatif Pengontrol Sistem Pelepasan Obat. Indonesian Journal of Chemical Science. 2013. 2 (3); pp. 190-193.
14. Stoica R, Şomoghi R, Ion RM. Preparation of ChitosanTripolyphosphate Nanoparticles For The Encapsulation of Polyphenols Extracted From Rose Hips. Digest Journal of Nanomaterials and Biostructures. 2013. 8 (3); pp. 955 963.

15. Zhang H, Allen, C, Kumacheva, E. Monodisperse chitosan nanoparticles for mucosal drug delivery. Biomacromolecules. 2004. 5; p. 2461.

16. Calvo P, Remun an-Lopez C, VilaJato JL, Alonso MJ. Chitosan and chitosan/ethylene oxide-propylene oxide block copolymer nanoparticles as novel carriers for proteins and vaccines. Pharm Res. 1997.14; pp.1431- 1436.

17. Swarbrick J. Encyclopedia of pharmaceutical technology. $3^{\text {rd }}$ ed. Vol. 4. Informa Healthcare USA Inc : New York. 2007.

18. Tiyaboonchai, W. Chitosan Nanoparticles: A Promising System for Drug Delivery. Naresuan University Journal. 2003. 11(3); pp. 51-66.

19. Liu H, Changyou G. Preparation and properties of ionically cross-linked chitosan nanoparticles. Polym. Adv. Technol. 2009. 20; pp. 613-619.

20. Dunne M, Corrigan OI, Ramtoola Z. Influence of particle size and dissolution conditions on the degradation properties of polylactideco-glycolide particles. Biomaterials. 2000. 21; pp. 1659-1668. 